\title{
NO-D0: Archivo y secuestro de la imaginación
}

\section{NO-D0: Public audiovisual archives and the kidnapping of imagination}

\author{
Enrique Fibla Gutiérrez \\ PhD Student Film and Moving Image Studies \\ (Concordia University Montreal)
}

Fecha de recepción: 9 de abril de 2014

Fecha de revisión: 21 de enero de 2015

Para citar este artículo: Fibla Gutiérrez ,E. (2015): N0-D0: Archivo y secuestro de la imaginación, Icono 14, volumen (13), pp. 294-313. doi: 10.7195/ri14.v13i1.713 


\section{Resumen}

Este artículo postula la necesidad de una nueva concepción de lo público digital en lo que a archivos audiovisuales se refiere. En lugar de pensar únicamente en la cuestión del acceso, se plantea también la inclusión del uso creativo del archivo como condición indispensable para la participación ciudadana en la institución del imaginario colectivo.

Como objeto de estudio se ha escogido el NO-DO, pieza fundamental para entender la relación entre poder e imaginario en la sociedad española. El hecho de que se permita su visualización por streaming, pero no su libre descarga plantea una serie de interrogantes sobre lo público digital y la relación entre poder y archivo hoy, cuestiones que serán desgranadas a lo largo del artículo, aportando ejemplos de qué sucede cuando el archivo permite lo que Cornelius Castoriadis llamó "El imaginario radical instituyente".

Palabras clave: Archivo - NO-DO - Imaginario - Poder - Imaginación - Imaginario radical instituyente - Público - Cornelius Castoriadis

\section{Abstract}

In 2012 the Spanish public television corporation (RTVE) and the Filmoteca Espanola presented the digitalization of the NO-DO newsreel, a public audiovisual heritage that is key to understand how the Franco dictatorship controlled the imaginary of the Spanish population. Until now this archive was accessible only in a physical location, and its use (both commercial and non-commercial) highly restricted.

The digitalization of the archive seemed to indicate a will to open the archive towards a more democratic understanding of the "public audiovisual". But the fact that the material can only be accessed through streaming but not downloaded for creative use raises a series of questions about the power relationship between digital public archives and political imaginaries. In this paper I suggest the need to rethink the archive as an "instituting" entity that should be open to the creative use of citizens, rather than become an "instituted" audiovisual cemetery.

Key Words: NO-DO - Public Archives - Political Imagination - Instituted Imaginary - Instituting Imaginary - Creative Use 


\section{Introducción}

Hace dos años (2012) RTVE y Filmoteca española presentaron la digitalización del noticiero N0-D0, un patrimonio audiovisual público clave ${ }^{1}$ para entender cómo la dictadura franquista y los primeros gobiernos en democracia dirigían la mirada, y por lo tanto el imaginario, de los españoles tanto al interior como al exterior de sus fronteras. Hasta entonces el fondo solo era accesible en celuloide, y su uso (tanto comercial como sin ánimo de lucro) celosamente controlado por el entramado burocrático del cual depende (Ministerio de Cultura, Filmoteca y RTVE). La digitalización del archivo parecía indicar una apertura en la concepción de lo público audiovisual ${ }^{2}$, pero el hecho de que el material tan sólo pueda ser visionado en streaming (acceso) pero no descargado (uso), plantea una serie de interrogantes sobre la relación entre archivo digital e imaginario político que este artículo pretende abordar. Mediante la teoría sobre el imaginario radical de Cornelius Castoriadis, plantearé la necesidad de abordar el archivo como entidad instituyente, en lugar de entenderlo como cementerio audiovisual instituido.

Empezaré por investigar hasta qué punto podemos denominar como público un archivo que no permite su uso creativo por parte de los ciudadanos. Así, exploraré el concepto de lo público en la era digital, proponiendo la necesidad de reevaluar los factores que lo determinan como tal. Dicho interrogante me llevará a tratar la relación entre poder y control del archivo, proponiendo el ejemplo del N0-D0 como paradigma de una concepción cuestionablemente democrática de la arqueología de medios como práctica creativa. Finalmente, postularé una nueva política del archivo como hogar del imaginario radical instituyente, abierto a nuevas significaciones y construcciones socio-políticas.

\section{El NO-DO y las imágenes de la memoria oficial}

En 1943 se inaugura un noticiero filmado de diez minutos de duración llamado NO-D0, el cual se proyecta obligatoriamente antes de cada película en los cines de toda España con el afán de presentar la visión del régimen de Franco tanto del mundo exterior como de lo que ocurre entre sus fronteras. Hasta mediados de los 
años setenta ofrecerá a los espectadores una imagen oficialista, manipulada, y en ocasiones delirante de la realidad socio-política del mundo 3 . En total se produjeron más de 4000 piezas, un patrimonio único para analizar cómo se fue construyendo una memoria audiovisual basada en un imaginario modelado por el poder. Por imaginario me remito a la definición que Jorge Bielinsky propone en su lectura de la obra de Jacques Le Goff (2007):

"Podría así definirse como conjunto de representaciones y referencias -en gran medida inconscientes- a través de las cuales una colectividad (una sociedad, una cultura) se percibe, se piensa e incluso se sueña, y obtiende de este modo una imagen de sí misma que da cuenta de su coherencia y hace posible su funcionamiento" (2007: 86).

En este sentido, la imagen que los españoles obtenían del N0-D0 dotaba de coherencia y normalidad a una realidad represiva y mezquina, enmascarada a duras penas por las imágenes de progreso y orden que el régimen difundía. Y es importante recordar que la implantación del noticiero supuso a su vez la prohibición de producir y circular otras documentaciones audiovisuales de la realidad, por lo que el N0-D0 era efectivamente el único medio disponible para ello. Fue, en definitiva, un formidable mecanismo para reformular la realidad y amoldarla a los propósitos del régimen, desde su consolidación como dictadura mal disimulada a su lento ocaso tras la muerte de Franco. Como sugieren Rafael R. Tranche y Vicente SánchezBiosca, el hecho de que el N0-D0 documente audiovisualmente gran parte de la dictadura implica que sus imágenes guardan sus múltiples interrogantes, siendo el más acuciante el por qué de la dilatación en el tiempo ante la apatía ciudadana (su mayoría) hasta mediados los años setenta (R. Tranche, Sánchez-Biosca, 2000 p. 18). Es por tanto necesario interrogar estas imágenes, no sólo desde el ámbito académico sino también desde la interpelación creativa, permitiendo que las respuestas salgan a la luz tras décadas de existencia subterránea.

Ya en los primeros segundos del noticiero, el cuatro de enero de 1943, se relacionan las palabras (el discurso) paz, progreso, trabajo, pueblo y caudillo, con el imaginario del régimen franquista, más concretamente con el palacio de El Pardo, el lugar de residencia del poder. Sobre un plano de Franco firmando papeles, se 
recuerda al público el "deber de los españoles de imitarle...cada uno en su esfera de acción y de trabajo ha de seguir esta línea de conducta...en beneficio de nuestra nación y nuestro pueblo". El NO-DO establece desde sus inicios una función adoctrinadora de la colectividad, a través de la repetición de una serie de símbolos (el orden militar, el crucifijo, la bandera, el caudillo, etc) que quedarán marcados en la memoria de los ciudadanos (figura 1).

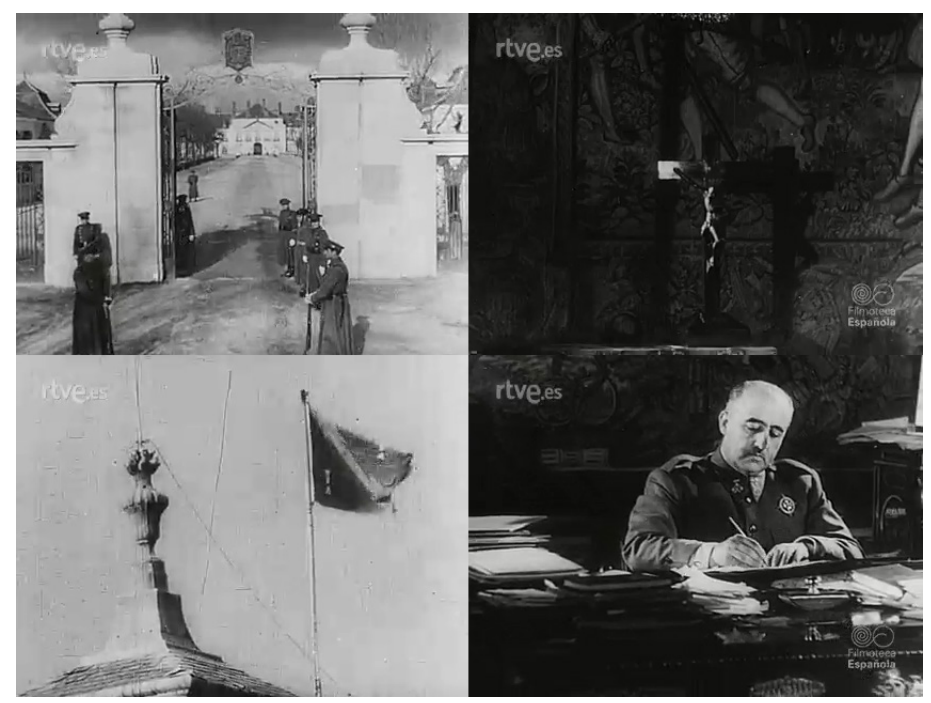

Figura 1: Primeros fotogramas del NO-DO. ${ }^{\circledR}$ Filmoteca Española.

Dicha materia simbólica se une al discurso narrado por el presentador del noticiero, construyendo un imaginario histórico que contribuyó en gran medida a la perpetuación del régimen como entidad inevitable. Quizás hoy en día se cuestione más el efecto de adoctrinamiento político de lo visual, habida cuenta de la explosión audiovisual que llevamos viviendo en los últimos años. Todavía se han de estudiar a fondo los efectos de la presente ubicuidad de lo visual, unida a la denominada democratización de los medios de producción, distribución y exhibición audiovisuales. Pero si nos atenemos al contexto histórico de la España de posguerra, en donde la televisión habría de esperar hasta mediados de los años sesenta para popularizarse en los hogares españoles, y el cine era la única pantalla disponible, la importancia del N0-D0 como aparato ideológico institutivo del franquismo resulta fundamental. 
Ciertamente, el noticiero proveía las imágenes y el discurso en las cuales se reflejaba (y se veía reflejada) la sociedad española, estableciendo una ontología de la misma basada en una institución política (el poder) que encarnaba las significaciones de obediencia, sumisión, orden y nación que caracterizan a cualquier gobierno autoritario. Como nos recuerda Cornelius Castoriadis (1997):

“La sociedad es creación, y creación de sí misma autocreación. Es la emergencia de una nueva forma ontológica -un nuevo eidos- y de un nuevo nivel y modo de ser. Es una cuasi totalidad cohesionada por las instituciones (lenguaje, normas, familia, modos de producción) y por las significaciones que estas instituciones encarnan (tótems, tabúes, dioses, Dios, polis, mercancía, riqueza, patria, etc.). Ambas -instituciones y significaciones- representan creaciones ontológicas" (p 4).

En este sentido, el NO-D0 proveía de normalidad a la existencia diaria de los ciudadanos bajo la dictadura. Paralizaba así el surgimiento de cualquier nueva ontología social, creando una sensación de inevitabilidad y alienación política que tardaría casi cuarenta años en romperse. Se produjo, en definitiva, un secuestro de la imaginación por el poder, un gesto que ha sobrevivido en democracia en su versión rebajada y aparentemente inocente; permitir el acceso a la memoria oficial, pero impedir su reelaboración crítica por parte del ciudadano, olvidando que la creación ontológica de la sociedad también se nutre de la memoria.

\section{Lo público en la era digital: imaginario instituido}

Como se ha establecido en el apartado anterior, la importancia del N0-D0 como patrimonio cultural es innegable, especialmente a la hora de analizar el imaginario franquista, y establecer sus supervivencias en la contemporaneidad. Evidentemente, el ministerio de cultura y RTVE también son plenamente conscientes de dicha importancia histórica, y han dedicado ingentes recursos y tiempo a catalogar, preservar y digitalizar el fondo. La diferencia radica más bien en lo que a la supervivencia de este imaginario se refiere, ya que la mentalidad institucional (de momento) plantea el archivo como instituido, como contenedor

ICONO14 | Año 2015 Volumen 13 NN $^{\circ}$ | ISSN: 1697-8293 | DOI: ri14.v13i1.713 
de una realidad histórica que ha quedado atrás y que no ha de mezclarse con el presente. En definitiva, se propugna una concepción de lo público digital como acceso y verificación, en lugar de aceptar también la vertiente creativa y abierta del archivo, aceptando que "cualquier documento encierra una parte del imaginario", y que interrogándolo se abandona "un imaginario acotado (y ya constituido) para deslizarse hacia sus formas de producción: hacia lo constituyente" (Bielinsky 2007, 84) ${ }^{4}$.

Así, si pensamos en la inmensa mayoría de proyectos que han hecho uso de sus imágenes (un uso que ha de ser autorizado previamente), vemos que el archivo adopta el rol de verificación mencionado, del esto pasó, fue así y aquí tienen las imágenes que lo corroboran. Por supuesto que no es la intención de este artículo despreciar dicho uso del archivo, sino plantear la necesidad de ir más allá en nuestra relación con el imaginario, o como Wolfgang Ernst afirma (2013), "An archivology of media does not simply analyze cultural archive but actively opens new kinds of archival action" (p. 29). Esta idea de realizar arqueología del archivo a través de la acción sólo puede ocurrir si no se ponen límites a la creatividad, es decir, si no se ejerce un control institucional sobre las imágenes públicas oficiales del pasado. Por ello propongo una relectura de lo público digital, basado en la necesidad de garantizar tanto el acceso como el uso creativo a la memoria audiovisual.

Con el actual sistema de streaming, se garantiza el acceso a las imágenes del NO-D0 desde cualquier dispositivo con conexión a Internet, lo cual es de vital importancia a la hora de facilitar la reflexión en torno al noticiero. Se cumple, pues, una de las dos variables que planteo como fundamentales a la hora de entender lo público digital. La visualización del NO-D0 ya no queda restringida a los investigadores, directores de documentales y algunos curiosos que habían de viajar al archivo físico en Madrid sí o sí simplemente para visionar el contenido. Ahora cualquiera con un poco de curiosidad puede acceder a sus contenidos, explorando el uso ideológico de lo visual por parte del régimen franquista, y poniéndolo en relación con la manera en que se estructura el imaginario socio-político hoy en día. Al fin y al cabo (Català 2012), “las imágenes gestionan la estructuración de nuestro imaginario" (p. 193) y la exposición del ciudadano al uso claramente ideológico 
del N0-D0 puede hacerle reflexionar sobre hasta qué punto dicha estructuración se moldea desde el poder, y qué parte de la misma sobrevive hoy en día.

Pero dicho avance se queda a medio camino, ya que visualizar un contenido y hacer uso creativo del mismo son dos cosas muy distintas. Efectivamente, RTVE no permite (legalmente al menos ${ }^{5}$ ) la descarga de los noticieros, tan sólo su visionado en streaming. Se impide por tanto el uso creativo de un material que es público a todos los niveles; su producción corrió a cargo del Estado, tiene un interés cultural colectivo innegable y su conservación, catalogación y digitalización ha sido costeada con dinero del contribuyente. ¿Por qué entonces no se ofrece su descarga libre y gratuita a disposición del ciudadano? Al fin y al cabo, la definición básica de lo público es que es algo de todos, a lo que podemos acceder y del que podemos hacer un uso libre siempre que respetemos las normas básicas de convivencia.

En la Web no se ofrece explicación alguna para esta decisión, por lo que me aventuraré a sugerir el por qué. Por un lado, el NO-DO ha resultado (y todavía lo es) un negocio lucrativo para las arcas públicas, ya que la cesión de uso de imágenes está regulado por decreto, concretamente en el BOE número 77 de 2006 . En él (ver figura 2) se detallan los precios por segundo del material, el cual varía según los usos que se hagan del mismo y los medios que quieran utilizarlo. Es cierto que se distingue entre un uso comercial y otro cultural o de carácter público, pero asumir que un ciudadano inquieto, con ganas de experimentar con su imaginario histórico, pague cuatro euros con cincuenta por cada segundo de metraje resulta cuanto menos cuestionable. Dicha mercantilización del legado cultural público dice mucho del concepto de valor que aplican a la cultura los guardianes de dicho patrimonio. Para ellos la digitalización del N0-D0 es una operación mercantil más, y en este caso con valor doble. Por un lado ofrece réditos políticos, ya que se trata de un proyecto de gran visibilidad a la hora de vender la inversión en patrimonio cultural público. Por otro lado, el hecho de que su uso esté sujeto a pago garantiza unos buenos ingresos (que probablemente cubre parte del presupuesto asignado a su conservación), a pesar de que ello imposibilite el uso creativo por parte de una ciudadanía a la cual le pertenecen dichas imágenes. 


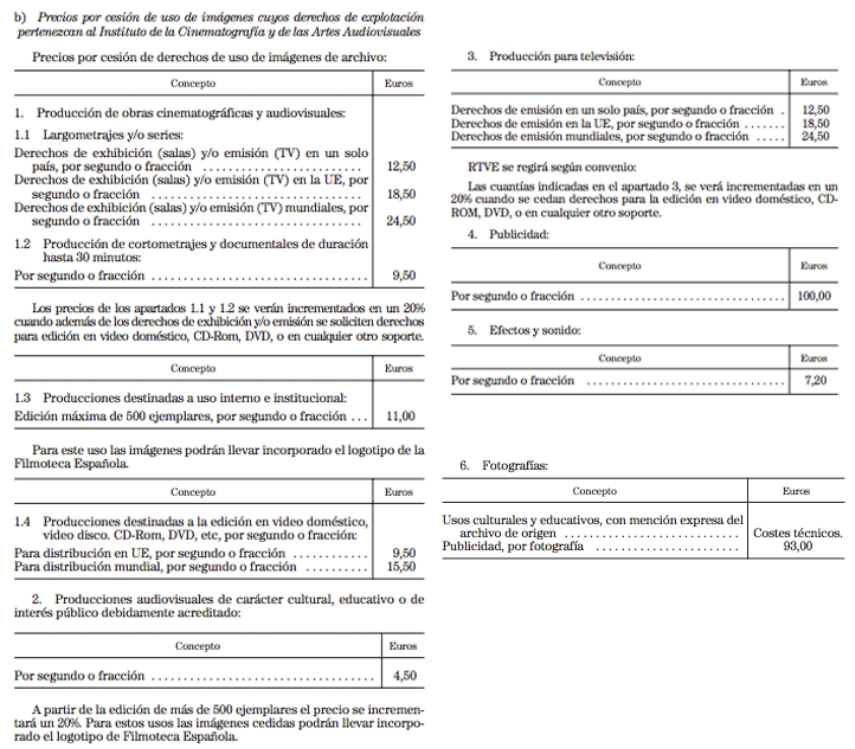

Figura 2: Tarifas de cesión de imágenes del Ministerio de Educación y Cultura. BOE núm 77, Viernes 31 de marzo de 2006.

Esta ceguera ante el verdadero valor que tiene el patrimonio cultural, lo que Nuncio Ordine denomina la utilidad de lo inútil, o el archivo como (2013) "tesoro que la colectividad debe preservar con celo a toda costa" (p. 10), es ciertamente preocupante, sobre todo cuando se propugna desde estamentos públicos. En este sentido, el valor que tienen las imágenes del NO-DO no es monetario, sino sociocultural. Es un testimonio indispensable para entender la relación entre ideología, imaginario y ciudadanía, y su uso creativo un sano ejercicio de imaginación, actividad que Ordine nos recuerda, en boca de Ionescu, (2013) "es tan indispensable como respirar" (p. 17). Sin embargo este aire tiene un precio prohibitivo, regido por una tabla de precios que pone en cuestión su cualidad de servicio cultural público y abierto.

Pero la mercantilización del N0-D0 no es la única causa que sugiero tras la actitud del Ministerio de Cultura. También está la relación entre archivo y poder, a la que Jacques Derrida alude en Archive Fever; a Freudian Impression, cuando escribe que (1995) 
"There is no political power without control of the archive, if not of memory. Effective democratization can always be measured by this essential criterion: the participation in and the access to the archive, its constitution, and its interpretation" (p. 11).

Derrida menciona no sólo la cuestión del acceso, sino también la participación en el archivo como medida de la calidad democrática del imaginario de una sociedad. En resumidas cuentas, cuanto más restringido esté el acceso y la participación en el archivo, menos democrático será el imaginario colectivo. Y el poder político bien sabe que dicho control sobre el pasado, o la memoria como escribe Derrida, es fundamental para sostener su posición en el presente y el futuro. En este sentido, el concepto de streaming tan sólo aprueba la prerrogativa del acceso, pero obvia por completo la de la participación. Al fin y al cabo, como su nombre indica, ésta tecnología no hace más que reproducir el tradicional esquema del emisor-receptor pasivo. Tampoco se permiten los comentarios de los usuarios, y el elemento participativo queda reducido a la función de compartir el vídeo a través de las redes sociales. Así, por mucho que nos llame la atención un determinado contenido ${ }^{6}$ y queramos explorar nuestra relación con él, tan sólo podremos contemplarlo las veces que queramos $\mathrm{y}$, como mucho, compartirlo vía Twitter o Facebook. El documento histórico se convierte entonces en anécdota, difícilmente en reflexión.

Ateniéndonos a las palabras de Derrida, la calidad democrática de lo público digital en el contexto español deja mucho que desear, imponiendo un control sobre la memoria que busca evitar la interrogación sobre el pasado para comprender el presente y el futuro (Ordine 2013, 96). Se fomenta así una sociedad desmemoriada, pero no en el sentido de que carezca de relación con las imágenes del pasado, sino en que ésta relación es pasiva, y por lo tanto difícilmente efectiva en lo que a ejercer la imaginación política se refiere. El archivo es el lugar donde el orden es dado (Derrida 1995, 1), y para que este ordenamiento de lo social sea un proceso instituyente y no instituido, ha de permitirse la emergencia del archivo reprimido $(1995,11)$, aquel que se manifiesta en la relación simultánea de las imágenes del pasado, presente y futuro.

ICONO14 | Año 2015 Volumen $13 N^{\circ} 1$ | ISSN: 1697-8293 | DOI: ri14.v13i1.713 
¿Pero por qué éste empeño en secuestrar el imaginario? ¿Por qué no permitir que se interroguen las imágenes del pasado para ponerlas en relación con las del presente? Porque, como nos recordaba Chris Marker en Sans Soleil (1976), permitir la participación (el uso creativo) en el archivo es aceptar que "si las imágenes del presente no cambian, cambia en su lugar las del pasado", por lo que el archivo abierto implica una potencialidad política que se realiza mediante su uso creativo. En el siguiente apartado exploraré varios ejemplos en este sentido, analizando qué sucede cuando se cambian las imágenes del pasado mediante el ejercicio de la imaginación.

\section{Imaginario radical instituyente}

En el festival de Gijón de 2010 se presentó la película Raza Remix (2010), del artista gironés Manel Bayo, una de las películas más interesantes (e infravaloradas) hasta la fecha en lo que a la creatividad de archivo se refiere. En ella, Bayo parte de la mítica película Raza (José Luis Sáenz de Heredia, 1941), una exaltación del nacionalismo español franquista, con guión del propio Francisco Franco. Mediante técnicas digitales, el director va añadiendo capas simbólicas al original, tejiendo un complejo (y tremendamente divertido) retablo surrealista, en donde emerge el inconsciente visual reprimido por décadas de imaginario oficialista. Tal ejercicio podría ser tachado de frivolidad estética, pero si se presta atención uno ve enseguida que cada animación añadida tiene su sentido y finalidad, poniendo sobre la pantalla el choque de dos iconografías; la del inconsciente reprimido y las imágenes del régimen represor -que luego serán trasladadas al NO-D0.

En cierto modo, el trabajo de Manel Bayo es un exorcismo de los demonios que se esconden tras el imaginario franquista. Imágenes de ley y orden, niños adoctrinados en la grandeza de la raza española, el culto a lo militar, la mujer obediente, la omnipresencia de la iglesia y su oscura moral, el sacrificio por la patria, etc. Raza Remix hace emerger el sustrato surrealista de dicha iconografía, haciendo evidente el carácter fantasioso de unas imágenes que pretendían describir la verdad y la pureza de lo español. Y dicho exorcismo tan sólo es posible a través del imaginario radical instituyente, que pone en relación esta dos iconografías para crear nuevas imágenes de pensamiento político-estético en la contemporaneidad.

DOI: ri14.v13i1.713 | ISSN: 1697-8293 | Año 2015 Volumen 13 N 1 | ICONO14 


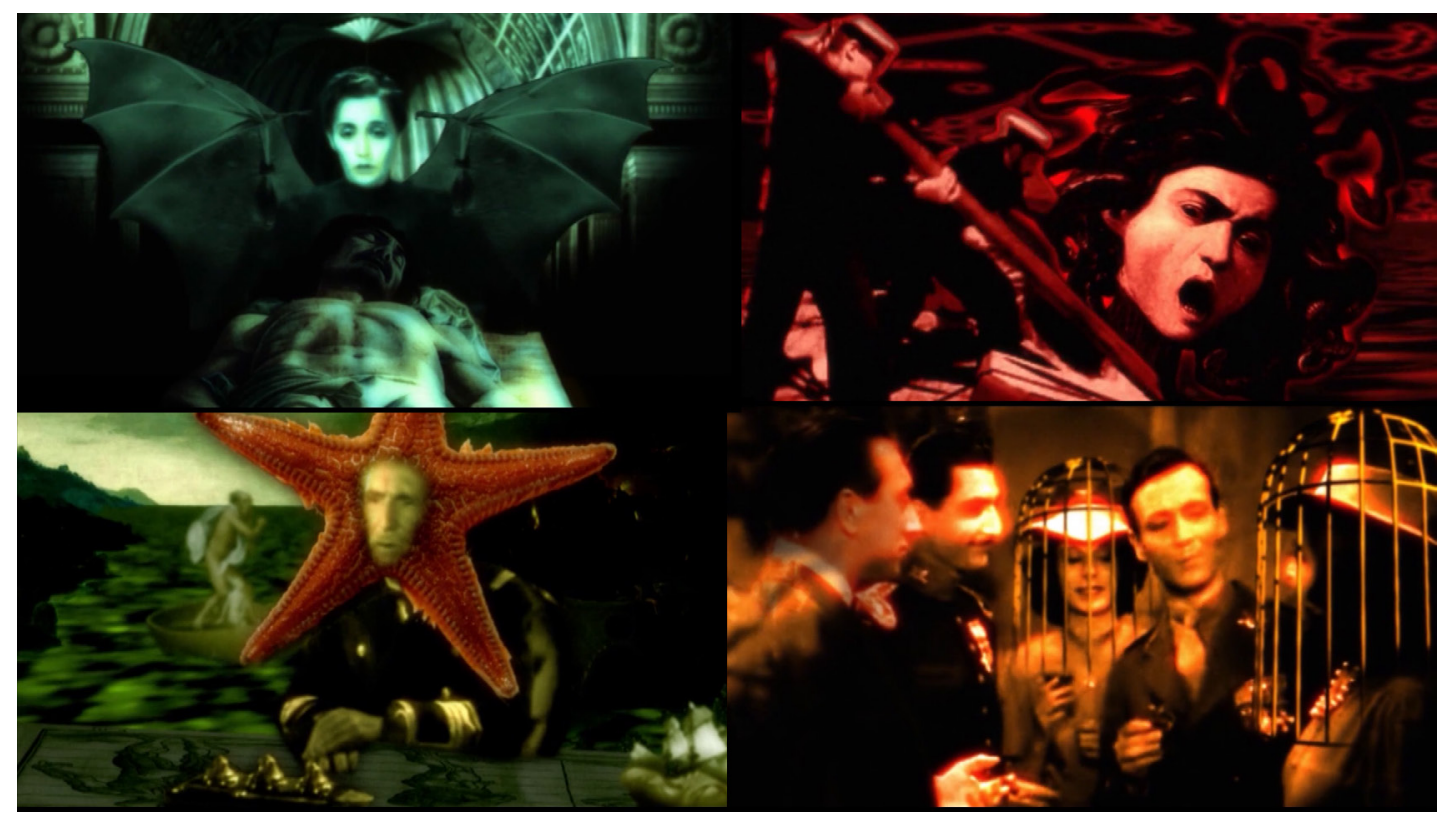

Figura 3: Fotogramas de Raza Remix (Manel Bayo, 2010). ๑ Manel Bayo.

¿Pero a qué me refiero con el imaginario radical instituyente? Para Cornelius Castoriadis, se trata de ese torrente subterráneo que fluye paralelo a la sociedad instituida, permitiéndonos de vez en cuando reformular y repensar lo social, aunque sea de manera aparentemente imperceptible $(1991,153)$. Es, por tanto, pura potencialidad, imagen latente que puede despertar en cualquier momento y hacer zozobrar lo instituido. Pero lo instituido sabe de éste peligro para su supervivencia, y como nos recuerda Castoriadis (1991) "against all of them, the institution of society establishes in advance and contains defenses and protections". (p. 153). El control del archivo es sin duda uno de estos mecanismos de protección, ya que el imaginario radical instituyente, como en el caso de Raza Remix, extrae las imágenes de su inofensiva temporalidad de pasado (esto sucedió, se filmó así y aquí quedó archivado) y las lanza al terreno inestable del presente y futuro, donde se instituye inciertamente la sociedad. Propongo, por tanto, una concepción del archivo público que también de cobijo al imaginario radical instituyente, permitiendo que éste se filtre a la superficie mediante una arqueología del acceso y uso creativo. 


\subsection{El perro negro y las historias subterráneas}

Para ilustrar un ejemplo concreto de cómo el imaginario radical instituyente puede hacer emerger realidades desde su fluir subterráneo, hablaré de la película El perro negro (2005) del director Húngaro Péter Forgács. En ella, la utilización de un material de archivo (películas caseras) sin aparente utilidad historiográfica abre en canal el discurso histórico oficial sobre la guerra civil, evidenciando las zonas grises e incómodas que pocas veces se han tratado con profundidad. Forgacs utiliza películas amateurs de una familia industrial catalana (los Salvans), mezclándolas con las filmaciones-diario de un joven (Ernesto Noriega) que se ve atrapado entre ambos bandos durante la guerra. Una voz en off ensambla estas (Ernst 2009) "piezas dislocadas de la naturaleza" (p. 13), uno de los muchos relatos subterráneos de un conflicto cuya complejidad ha quedado enterrada bajo la dicotomía republicanos-sublevados. Forgacs intenta desenterrar esta complejidad mediante la imaginación, poniendo imágenes y sonidos a las abstracciones que conforman dicha lectura simplista de la guerra civil.

Así, la abstracción burguesía industrial se personaliza en los avatares de la familia Salvans en su finca La Barata durante los años 30'. Viven aparentemente ajenos a las turbulencias sociales que conducirían al conflicto armado y al posterior asesinato del padre y el hijo a manos del anarquista Pedro el cruel, tan sólo seis días después de estallar el conflicto . Por otra parte, las grabaciones y palabras del joven estudiante y cinéfilo Ernesto Noriega hacen visible la realidad de una ciudadanía confundida y atrapada en un conflicto ideológico en donde solo cuenta sobrevivir. El discurso histórico del narrador se sobrepone a imágenes (la mayoría filmaciones amateurs) que no necesariamente representan los hechos exactos, pero que están conectadas con ellos mediante tangentes que proceden del imaginario. Se produce una colisión entre memoria particular e historicismo, haciéndonos ver que la guerra no es solo una abstracción geopolítica con dos bandos claramente diferenciados sobre el tablero, sino también infinitas historias personales que tienen lugar entre el caos creado por estas posiciones. De ahí las imágenes recurrentes del perro negro vagabundeando que dan título a la película, apenas unos segundos de los cuales no recibimos contexto alguno, pero que nos recuerdan que no estamos únicamente ante la historia particular de la familia Salvans o Ernesta Noriega, sino

DOI: ri14.v13i1.713 | ISSN: 1697-8293 | Año 2015 Volumen 13 N 1 | ICONO14 
de las historias que nunca formarán parte de la historiografía oficial, y vagarán por el olvido como ese animal fantasmagórico que sale de cuadro (figura 4).

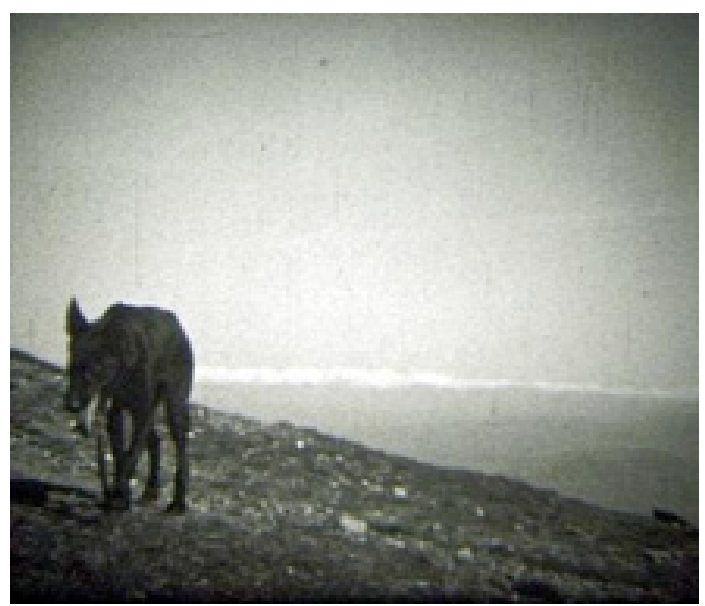

Figura 4: Fotograma de El Perro Negro (Péter Forgács, 2005). ๑ Péter Forgács.

Este uso alegórico de la imagen es clave para entender los mecanismos por los cuales el imaginario radical instituyente se da. La puesta en común de una serie de imágenes aparentemente no relacionadas permite conexiones insospechadas entre las mismas, de donde súbitamente se manifiesta lo subterráneo, lo que había permanecido oculto bajo capas de discurso oficial. En las películas amateurs de Salvans sorprende la reiterada escenificación de peleas, duelos y luchas con un claro vencedor, un triste presagio que pasará de la representación a la realidad en apenas unos años, pero que también nos habla de la inocente distancia que imponía la burguesía con su realidad histórica. Más adelante, la quema de edificios religiosos durante la segunda república es confrontado con una pieza del industrial catalán en donde vemos a un hombre que ha perdido la cabeza, una perfecta metáfora del desastre que los extremismos comportarían para el país. Una división resumida en la historia de Noriega, acusado absurdamente por los republicanos de pertenecer al levantamiento, encarcelado y a punto de ser fusilado. Sus grabaciones clandestinas en la prisión, y la pulsión de grabar su realidad cercana se convierten a ojos del espectador en un gesto desesperado por encontrar algún significado a la barbarie del conflicto. 
El acierto de Péter Forgács es por tanto el de hacer historiografía mediante el dispositivo cinematográfico (Ernst 2009) "sin considerar la diferencia temporal como una distancia insalvable" (p. 17), sino más bien como aquello que permite la emergencia del imaginario reprimido. Sin embargo, El perro negro se debe todavía a una concepción del uso de material de archivo público como circunstancia excepcional, reservada a un director conocido y probablemente sujeta al pago correspondiente por la cesión de imágenes ${ }^{7}$. Es decir, el archivo del cual se nutre es tan sólo parcialmente abierto, y desde luego cerrado al libre uso creativo por parte del ciudadano. Propongo examinar una película en donde se ha hecho uso de archivos verdaderamente públicos, cuyo contenido puede encontrarse en la plataforma Archive.org, y que muestran por tanto las posibilidades creativas del archivo abierto al ciudadano.

\subsection{Caroline Martel y el hogar de los fantasmas}

A mediados de los años noventa se fundó The Internet Archive, una institución sin ánimo de lucro con sede en San Francisco, que dedica sus esfuerzos a crear la liberaría de Alejandría de la era digital. A través del portal archive.org, uno puede acceder libremente a una ingente cantidad de artefactos culturales (audio, textos, películas, conferencias etc.), muchos de ellos bajo licencias Creative Commons que permiten su uso creativo. Como indican en su propia página Web, "without cultural artifacts, civilization has no memory and no mechanism to learn from its successes and failures" ${ }^{\prime \prime}$. Su misión es por tanto la de garantizar el acceso a dicho material, pero también la descarga legal de muchos de sus contenidos, fomentando conceptos como remix o reapropiación, claves a la hora de entender el uso creativo del archivo.

Centrándonos en el contenido audiovisual de archive.org, llama la atención la importancia otorgada a las ephemeral films, o películas huérfanas (por la ausencia de un dueño legal) que conforman las colecciones de Prelinger Archives o A/V Geeks entre otras. Se trata de películas caseras, filmes corporativos, documentales divulgativos producidos por gobiernos, noticieros, anuncios, stock footage y un largo y fascinante etc. A pesar de su innegable valor como artefactos culturales (por ejemplo a la hora de analizar el papel de la cultura visual en la creación de

DOI: ri14.v13i1.713 | ISSN: 1697-8293 | Año 2015 Volumen 13 Nº 1 | ICONO14 
discursos hegemónicos de todo tipo), nadie se había preocupado por preservarlos, hasta que una serie de particulares (Rick Prelinger, Skip Elsheimer o Craig Baldwin entre otros) comenzaron a hacerlo en la década de los noventa. La decisión de digitalizar paulatinamente estos contenidos y ofrecerlos al público ha descubierto a creadores de todo el mundo un repositorio inagotable de fantasmas audiovisuales, los cuales, como el perro negro de Forgacs, se pasean por creaciones de todo tipo.

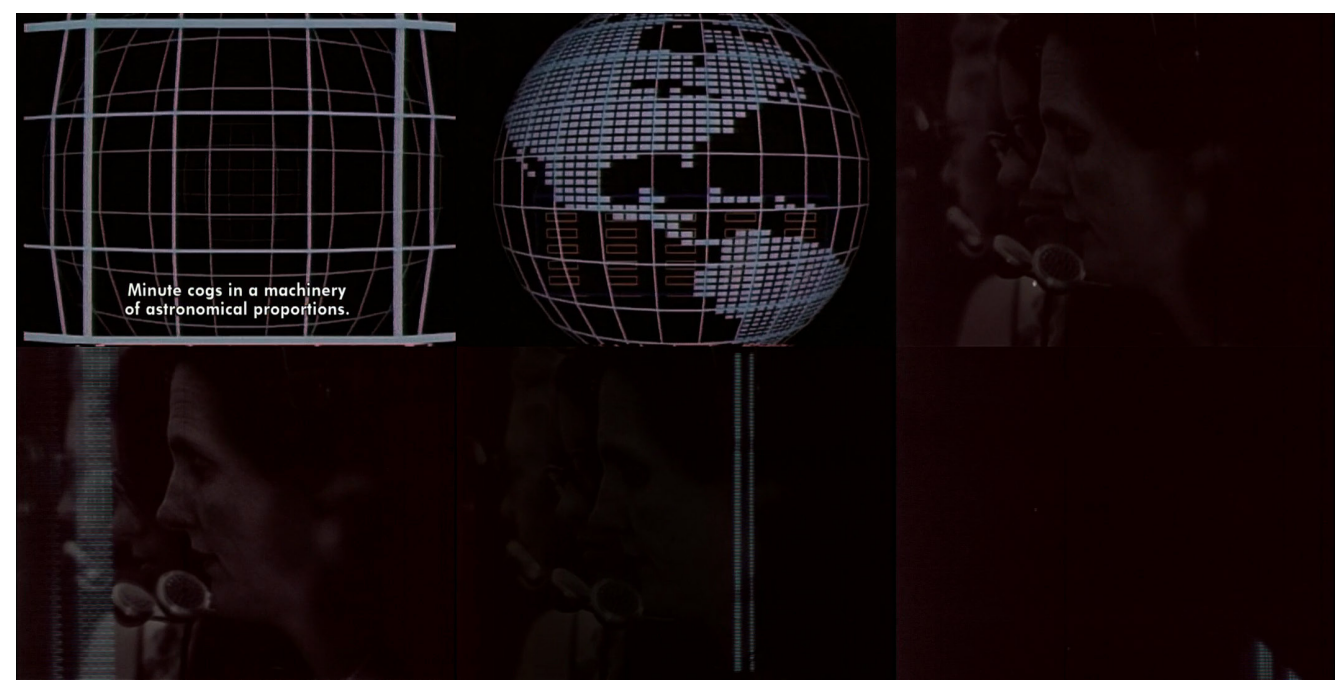

Figura 5: Fotogramas de Le fantôme de l'opératrice (Caroline Martel 2006). Caroline Martel.

Sirva de ejemplo Le fantôme de l'opératrice (Caroline Martel 2006), una película que hacen un uso muy interesante del archivo público para explorar una historia subterránea, parte de un imaginario reprimido que emerge para instituir una nueva realidad histórica. La película narra la desaparición de la mano de obra femenina (tras su aparente incorporación al mercado laboral durante la segunda guerra mundial) en detrimento de la técnica. Centrándose en la progresiva desaparición de las operadoras telefónicas que conectaban las llamadas en Canadá (convertidas al final en una voz electrónica), Martel construye un potente discurso sobre la deshumanización de la producción industrial, y la marginación de la mujer en el mercado laboral tras la ilusión de los tiempos de guerra. ¿Cómo contar esta historia de espectralización industrial? La directora opta por una respuesta imaginativa, reapropiándose de material de archivo huérfano (en este caso películas promocio- 
nales de la compañía telefónica Bell) y trabajando el silencio que guardan dichas imágenes. Josep M. Català ha tratado recientemente este concepto de silencio visual, definiéndolo como (2012) "lo real que resta tras la poda del discurso" (p. 283). Es decir, aquello que late bajo el discurso, ya que:

Las imágenes susurran un conocimiento que no pueden expresar las palabras 0 , mejor dicho, que no proviene de las palabras, del mundo organizado como lenguaje, sino de las profundidades del imaginario, o como querían los surrealistas, del inconsciente. (p. 98)

Caroline Martel hace susurrar a estás imágenes-fantasma sin necesidad de insertarlas en un discurso documental clásico, ya que lo importante no es a qué se refieren exactamente, sino qué nos dicen sobre el imaginario que subyace en ellas, en su modo de producción y relación con otras imágenes similares. Una vez más el uso de la alegoría es fundamental, ya que la etérea voz en off (no sabemos quién nos narra, por qué y desde dónde), unida al uso de superposiciones $\mathrm{y}$ fundidos encadenados entre diferentes materiales de archivo (figura 5) nos remiten constantemente a la idea de una imagen (una realidad) que desaparece bajo otra de manera casi imperceptible, de la misma manera que nuestra entrega irreflexiva a la tecnología elimina mercados laborales sin que seamos muy conscientes de ello.

Le fantôme de l'opératrice utiliza el archivo como articulador de un discurso silenciado por el progreso industrial y su maquinaria visual, utilizando sus mismas imágenes para devolver un reflejo que muestra (Català 2012) "el poso imaginario que reside en lo real" (225). Así, el ejercicio de mostrar al público el rostro tras el aparato en las películas corporativas de Bell está ligado al deseo patriarcal de controlar la imagen de la mujer trabajadora (quien siempre aparece dócil bajo el control del responsable masculino). A su vez, la posterior irrupción de imágenes electrónicas (figura 5) entronca con la fascinación que la técnica produce en el imaginario del progreso capitalista, repleto de referencias a satélites, circuitos, velocidad, datos, transacciones e imágenes de la globalidad. En apenas unos años la figura de las trabajadoras desaparece del discurso visual, a la vez que lo hace en el mundo real, reemplazadas por las voces electrónicas. Todo presentado (y nor- 
malizado) con un discurso visual didáctico y hegemónico, al que Caroline Martel hace oposición mediante el imaginario radical instituyente, desenterrando el poso ideológico de dichas imágenes mediante un paciente ejercicio de interrogación fílmica. Su trabajo deja al descubierto todo aquello que las tecno-utopías pretenden hacernos olvidar con su propensión a la desmemoria; los escombros de una realidad derribada en aras del progreso.

\section{Conclusión}

En este artículo se ha argumentado la necesidad de cambiar la concepción de lo público en la era digital, empezando por quienes ostentan el control sobre el archivo. Es fundamental que dicha gente entienda la importancia socio-política del archivo abierto, y la posibilidades creativas del imaginario radical instituyente. Convencerles de que lo contrario implica seguir la misma lógica inicial del N0-D0; el control del imaginario por parte del poder, sólo que en este caso la exclusividad no se refiere a la producción de imágenes sobre la realidad cotidiana, sino al libre uso de las mismas por parte del ciudadano. Y esto nos conduce irremediablemente a una sociedad afásica respecto a su memoria, incapaz de utilizarla para reestructurar el porvenir. Por ello, se interpela al lector a hacerse escuchar, a exigir (de la manera que prefiera) un archivo público que garantice acceso y uso creativo, compartiendo ejemplos como los que se han analizado en este artículo.

Me gustaría concluir con una reflexión sobre la necesidad de seguir interrogando el imaginario, algo que el cineasta Standish Lawder nos recuerda en relación al significado oculto de las imágenes, afirmando que (Zyrd 2003) "what was filmed remains firmly fixed, only now surrounded by a thousand possible new whys" ( $\mathrm{p}$. 51). Los múltiples por qué de las imágenes del N0-D0 están encerrados bajo un concepto cuestionable del archivo público, y de momento tan sólo ven la luz cuando algún cineasta o académico sortea el entramado burocrático y económico que los acota. Dicha capacidad de preguntarle, de hacerle cosquillas a nuestra memoria audiovisual para que emerjan sus capas subterráneas, no puede ser el privilegio de unos pocos. Al menos si lo que queremos es una sociedad que acepte el imaginario como instituyente, abierto a nuevas significaciones.

ICONO14 | Año 2015 Volumen $13 N^{\circ} 1$ | ISSN: 1697-8293 | DOI: ri14.v13i1.713 
Hoy en día se habla mucho de la necesidad de una nueva realidad, un nuevo horizonte socio-político que supere el agotado discurso actual. Propongo hacer caso a Josep M. Català cuando sugiere que (2012) “la nueva realidad hay que pensarla, gestionarla y conducirla desde la imaginación" (p. 42). Un buen lugar por donde comenzar es reclamar el (des)control del archivo público, permitir su libre uso creativo para que el ciudadano examine creativamente la memoria audiovisual oficial. Sólo así podremos comprender cómo se instituyó el imaginario socio-político que intentamos dejar atrás, para después empezar a instituir, sin clausurarlo jamás, un presente y un futuro en perpetua reinvención.

\section{Notas}

[1] La propia página de RTVE lo define como "el mayor patrimonio audiovisual de España. Recuperado de http://www.rtve.es/noticias/20121220/archivo-filmoteca-no-do-mayor-fondohistorico-audiovisual/590521.shtml

[2] En la Web del NO-D0 se anuncia que "En diciembre de 2012 RTVE.ES y Filmoteca abren estos documentos excepcionales de la historia de la transformación de España a su consulta libre en Internet." Sobre el NO-D0. Recuperado de http://www.rtve.es/filmoteca/no-do/historia). Accedido el 24 de marzo 2014

[3] Con la llegada de la democracia su exhibición dejó de ser obligatoria, y finalmente el N0-D0 sería cancelado en 1981. Para más información consultar el libro de Rafael R. Tranche y Vicente Sánchez-Biosca (2000) NO-D0: El tiempo y la memoria. Ediciones Cátedra.

[4] Es importante resaltar que en este artículo equipararé los términos constituido y constituyente de Bielinsky con sus homónimos instituido e instituyente, que Cornelius Castoriadis utiliza en su descripción del imaginario.

[5] En la era de la piratería siempre hay una manera, aunque los métodos que se pueden encontrar en la red tan sólo permiten una descarga de baja calidad (acorde con el archivo original subido para streaming), por lo que el uso creativo queda restringido a la ilegalidad y las pequeñas pantallas.

[6] Vuelvo a reiterar que la labor de digitalización y catalogación es ejemplar y loable. El contenido de los noticieros ha sido cuidadosamente indexado, lo cual permite al usuario acceder directamente al contenido específico de un NO-D0 sin tener que visionarlo en su totalidad.

[7] No pretendo restarle mérito alguno a la excepcional película de Péter Forgács, tan solo resaltar una característica de su proceso de producción que me parece pertinente en mi argumentación a favor de un archivo verdaderamente público.

[8] Why the Archive is Building an 'Internet Library'. Recuperado de https://archive.org/about/

DOI: ri14.v13i1.713 | ISSN: 1697-8293 | Año 2015 Volumen 13 Nº 1 | ICONO14 


\section{Referencias}

Adorno, T. W. (2007). Aesthetics and politics. London; New York, NY: Verso. Alphen, E. Van. (2009). Ernst van Alphen Hacia una nueva historiografía: Péter Forgács y la estética de la temporalidad. Estudios Visuales, 6, 30-48. Bayo, Manel. Raza Remix. Copia digital. Dirigida por Manel Bayo. 2010. Belinsky, J. (2007). Lo imaginario: un estudio. Buenos Aires: Nueva Visión. Berger, J. (2007). Modos de ver. Barcelona: Gustavo Gili.

Català, J. M. C. D. (2012). El murmullo de las imágenes. Santander: Shangrila.

Castoriadis, C. (2013). La institución imaginaria de la sociedad. Barcelona: Fábula. Castoriadis, C. (1997). El imaginario social instituyente. Zona Erógena, 35, 1-9.

Castoriadis, C., \& Curtis, D. A. (1991). Philosophy, politics, autonomy. New York: 0xford University Press.

Ernst, W. (2013). Digital memory and the archive. Minneapolis: University of Minnesota Press.

Forgács, Péter. El Perro Negro. Copia digital. Dirigida por Péter Forgács. 2005

Marker, Chris. Sans Soleil. DVD. Dirigida por Chris Marker. Barcelona: Intermedio, 1976

Martel, Caroline. Le fantôme de l'opératrice. Copia digital. Dirigida por Caroline Martel. 2004.

Merewether, C. (Ed.). (2006). The archive. London : Cambridge, Mass: Whitechapel ; MIT Press.

Torlasco, D. (2013). The heretical archive: digital memory at the end of film. Minneapolis ; London: University of Minnesota Press.

Tranche, R. R., \& LC Collection (Library of Congress). (2000). NO-D0: el tiempo y la memoria. Madrid: Cátedra : Filmoteca Española.

Zyrd, M. (2003). "Found Footage Film as discursive Metahistory". The Moving Image $3(2), 40-61$. 